\title{
Urban Primacy, Gigantism, and International Trade: Evidence from Asia and the Americas
}

\author{
Ronald L. Moomaw \\ Oklahoma State University \\ Mohammed A. Alwosabi \\ University of Bahrain
}

\begin{abstract}
Gustavsson [1999] finds that policies that promote international trade increase the size of a country's largest city relative to the country's total population, which is defined here as an increase in urban gigantism. In contrast, Ades and Glaeser [1995] report urban gigantism is reduced by freer political institutions and, with less confidence, more open trade. In light of Henderson's (2000) findings that excessive urban concentration inhibits economic growth, these conflicting results for the relationship between openness and urban gigantism (concentration), which are of great interest for the new economic geography, call for additional study. This study uses two measures of urban concentration and finds that lower international-trade costs are associated with lower primacy, but not with lower gigantism. Unlike Gustavsson, however, we find no evidence that lower trade costs increase gigantism.
\end{abstract}

- JEL classification: O18, R12

- Keywords: Economic development, Economic geography, Urban Concentration

\footnotetext{
*Corresponding address: Ronald L. Moomaw, Department of Economics, Oklahoma State University, Stillwater, OK 74078 Phone: 405-744-7359, Fax: 405-744-5180, E-mail: Rmoomaw@okstate.edu 


\section{Introduction}

Advances in urban economics and the new economy geography, discussed in Brakman et al. (2001), Fujita et al. (1999), Henderson (1996), and Krugman (1996) have revived interest in the effects of economic development, political economy, and international trade on urban concentration, particularly in developing countries. Henderson's finding (2000) that excessive urban concentration inhibits economic growth heightens the importance of understanding its determinants. In this regard, Gustavsson's (1999) report that restrictive trade policies reduce the size of a country's main city relative to its urbanized population - called gigantism in this study - is of great importance. Other studies have found that trade openness or lower trade costs reduce similar measures of urban concentration. Ades and Glaeser (1995), for instance, report that restrictive international trade policies have contributed to gigantism, but their result is not robust. Moomaw and Shatter (1996) report that larger export shares of GDP are associated with reduced gigantism. Given the diversity of results, the first purpose of this paper is to provide additional information about the effects of international-trade costs on urban concentration.

Ades and Glaeser (1995) also find that the percentage of labor outside agriculture, a development indicator, also has a positive effect on main-city size, but they do not find an association between it and real GDP per capita. Moomaw and Shatter (1996) find that higher literacy levels, another development indicator, increase gigantism. So, a second purpose of this paper is to examine the link between development and urban concentration.

Besides conflicting findings regarding the effects of trade costs, these papers do not deal with urban primacy as originally defined. Jefferson (1939) originally defined it as the ratio of the population of the largest city to that of the second largest city. Several primacy ratios, incorporating the largest city and the next largest cities, have been used (Mutlu 1989), as have summary measures of the size distribution of cities, such as the Herfindahl index and a parameter of the Pareto distribution (Mutlu 1989; Rosen and Resnick 1980; and Wheaton and Shishido 1981). Among students of economic development, excessive primacy raises concern (supported by (Henderson 2000)) that a large city, which is "too large" given the system of cities, may retard development (Sawers 1989). A city that dominates the rest of the country may adversely affect the growth of other cities and economic diversification among regions. In the urban primacy literature, much emphasis has been put on the possibility that excessive concentration or primacy in 
low-income countries may arise from the workings of the political process, a result supported by AG (1995).

It would be convenient if the size of the largest city relative to total population or to urbanized population could serve as a proxy for primacy ratios and summary size-distribution measures. Certainly, the larger the main city, other things equal, the greater the dominance of the main city. ${ }^{1}$ Consequently, another purpose of this paper is to determine how closely the determinants of gigantism match the determinants of the primacy ratio. The primacy ratio is emphasized rather than summary measures of the size distribution because of the cost of collecting the data necessary to construct a panel of size-distribution measures. ${ }^{2}$

Table 1 shows the correlations among primacy ratios that others have used to measure urban concentration. The ratios of main-city to second-city population and main-city to the sum of the populations of cities 2 through 4 have a simple correlation coefficient of 0.98 , suggesting that the two variables measure essentially the same concept. The correlations with the ratio of main-city population to urbanized population - implicitly the ratio used by Ades and Glaeser - are smaller, 0.69 and 0.70 ; those with the main-city national-population ratio are 0.39 and 0.34 . Although these correlations are significant, they imply that only one-half of the variation in the two- and four-city ratios is common to the variation in the ratio of main-city population to urbanized population. The information in the two-city primacy ratio may be sufficiently different that understanding the determinants of main-city size, holding urbanized population

Table 1. Correlation Matrix of Urban Concentration Indices

\begin{tabular}{lcccc}
\hline & 1 & 2 & 3 & 4 \\
\hline $\begin{array}{l}\text { 1. Main city population divided by second city population } \\
\text { 2. Main city population divided by the sum of the popula- }\end{array}$ & 0.00 & & & \\
tion of the next three cities. & & & & \\
3. Main city population divided by urbanized population. & 0.69 & 0.70 & 1.00 & \\
4. Main city population divided by total population. & 0.39 & 0.34 & 0.62 & 1.00 \\
\hline
\end{tabular}

'This is essentially the approach taken by Moomaw and Shatter (1996) who examine the determinants of urban primacy, where primacy is measured by the population of a country's largest city as a share of the national population.

${ }^{2}$ Because of the panel approach taken here, summary measures of the size distribution, such as the Herfindahl index and the Pareto coefficient, are too costly in terms of data. They would require a panel of size distributions by country. See Henderson (1988) and Rosen and Resnick (1980) for studies that use summary measures. 
constant, does not provide an understanding of the primacy.

Urban concentration is a focus of neoclassical urban systems and of the new economic geography (Henderson 1996). In modeling urban concentration, Krugman (1996) lists four stylized facts as cornerstones. They are that urban concentration (1) falls with income per capita, (2) increases with the concentration of political power, (3) is affected by the transportation infrastructure, and (4) falls with trade openness. His empirical support for these stylized facts is limited. His specific references are to Ades and Glaeser (AG) for fact 2 and to Rosen and Resnick for facts 3 and 4 . In light of the increasing importance of the new economic geography, the paper's final purpose is to provide more information on Krugman's stylized facts.

In this paper we use the AG framework to understand the effects of international-trade costs on gigantism and primacy and to compare their determinants. We use the same equation to explain the two variables because we want to see if studying urban primacy provides useful information additional to that obtained from studying main-city size. First, we apply the Ades-Glaeser equation and method to our data to estimate the determinants of main-city size and urban primacy. We then use panel-data techniques to estimate the equations. Our paper extends the recent economics literature on urban concentration in several ways. First, it contributes to the understanding of the relationship between trade costs and concentration. Second, its focus is on urban primacy, using a more traditional measure. Third, it specifically compares the determinants of urban primacy and main-city size. Fourth, it uses panel data in five-year intervals from 1960 to 1990 and exploits it with the fixed-effects estimator. Fifth, it estimates the determinants of the fixed effects.

Our results on trade costs are consistent with the implications of the new economic geography and with the tentative empirical results that lower international-costs costs reduce urban concentration. We find no support for Gustavsson's result that trade restrictions reduce gigantism. Although our results are generally consistent with those of Ades and Glaeser, we also find that urban concentration cannot be analyzed completely with main-city size as the variable explained. Finally, with appropriate modification, the results conform to Krugman's stylized facts concerning urban concentration. 


\section{The Determinants of Gigantism and Urban Primacy: A Cross-Section Approach}

\section{A. The Data}

Ades and Glaeser average their data over four years $(1970,1975,1980$, and 1985) for 85 countries and Gustavsson averages data over the decade of the 1980s (where possible) for 34 third-world countries. We limited our sample to 30 countries from Asia and the Americas, but we construct a thirty-year panel (in fiveyear increments). Most of the observed variation regarding gigantism and primacy is present in the sample. For instance, rapid urbanization and mega-cities exist in both Asian and American countries. The sample includes a variety of countries: developed, less developed and those experiencing rapid or slow growth. Each country satisfies the following criteria: (1) a total population of two million or more in 1990, (2) a nation-state not a city-state, eliminating Hong Kong and Singapore, and (3) not a socialist or ex-socialist country. These criteria give 33 countries. Because of data unavailability, we drop Haiti, Jamaica, and Nepal. Therefore, our sample includes 30 countries: 11 countries from Asia, 17 from Latin America, and 2 from North America ${ }^{3}$.

This sample includes countries with very large population such as India with about 850 million people in 1990 and countries such as Panama with only about 2.5 million (See Table 2 for descriptive statistics). It includes among the main cities, mega-cities such as Tokyo with more than 25 million inhabitants in 1990 and smaller cities such as San Jose (capital of Costa Rica) with 297 thousand inhabitants. It also encompasses a wide range of development, from low-income countries such as India with GDP per capita of $\$ 1,264$ in (PPP) to high-income countries such as the United States, $\$ 18,054$ in 1990 . Some countries have a highly primate city, for instance, Thailand with its main city 26 times larger than its second city; others, such as Canada, have a main city with much less than twice the population of the second city.

\section{B. The Specification and Cross-Section Results}

Ades and Glaeser rely on Krugman and Elizondo (1996), as does Gustavsson

\footnotetext{
${ }^{3}$ The 30 countries, in alphabetical order, are: Argentina, Bangladesh, Bolivia, Brazil, Canada, Chile, Colombia, Costa Rica, Dominican Republic, Ecuador, El-Salvador, Guatemala, Honduras, India, Indonesia, Japan, Korea (south), Malaysia, Mexico, Pakistan, Panama, Paraguay, Peru, Philippines, Sri Lanka, Taiwan, Thailand, United States, Uruguay, and Venezuela.
} 
Table 2. Descriptive statistics 1990 values

\begin{tabular}{lccccc}
\hline \multicolumn{1}{c}{ Variable } & Obs. & Mean & Std. Dev. & Minimum & Maximum \\
\hline Primacy Ratio & 30 & 5.1778 & 5.5609 & 1.138 & 25.49 \\
Gross Domestic Product * & 30 & 368570 & 867790 & 6983 & 4520000 \\
GDP per capita & 30 & 4612.0 & 4426.7 & 1264 & 18050 \\
Population* & 30 & 75700 & 158300 & 2418 & 849500 \\
Main-City Population* & 30 & 6203.5 & 6266.0 & 297.0 & 25010 \\
Arable Land Area & 30 & 20127 & 44544 & 285.0 & 187900 \\
Population Density & 30 & 8.2797 & 7.3156 & 0.5782 & 29.98 \\
Capital City Indicator & 30 & 0.80000 & 0.40684 & 0.0000 & 1.000 \\
Exports/GDP & 30 & 27.600 & 18.301 & 7.00 & 91.00 \\
Nonagricultural Employment & 30 & 0.67073 & 0.19089 & 0.3150 & 0.9720 \\
Dictatorship Indicator & 30 & 1.5000 & 0.50855 & 1.000 & 2.000 \\
*(000) & & & & & \\
\hline
\end{tabular}

(1999), for the hypotheses that urban concentration will increase with internal transportation costs and decrease with international trade. ${ }^{4}$ Krugman's hypothesis regarding the role of trade costs is based on the importance of the economy's size in realizing economies of scale. In the presence of agglomeration economies, the total demand for specialized products (intermediate or final goods) in a small, closed economy may support only one viable production site. The site could develop into a very large city, giving the country a large primacy ratio. If the same economy were open and had sufficiently low international-trade costs, the specialized products, which would otherwise be produced in the large city, could be imported, loosening the tie that binds firms to the main city. In addition, if firms can export specialized goods, which otherwise could only be sold in a large city, their ties to the economy's main city are loosened. AG use the share of trade in GDP and in some instances, a measure of tariffs, to test the international trade hypothesis. Gustavsson uses indicators of the share of trade in GDP, tariffs, and non-tariff barriers in a similar test.

In Ades and Glaeser's framework, the results of the tradeoff between economies of scale and transportation costs are captured by controlling the country's population, land area, GDP per capita, and nonagricultural employment. ${ }^{5}$

\footnotetext{
${ }^{4}$ In addition, Brueckner (1990) and Wheaton and Shishido (1981), among others, emphasize transportation costs and economic development as determinants of urban concentration.

${ }^{5}$ Ades and Glaeser expect concentration to increase with industrialization because it requires more infrastructure that in turn leads to concentration because of economies of scale.
} 
Gustavsson, on the other hand, controls so-called push and pull factors with rural population density, road density, and in some estimates GDP per capita. Conditional on an economy's size and development, Ades and Glaeser develop a model of the effects of dictatorship and political instability on main-city size. They analyze urban concentration assuming that government taxes capital-city and hinterland residents so as to maximize a utility function with government rents and survival as arguments. The capital city or main city must be treated with care because, by assumption, successful coups originate there. The hinterland can be taxed more heavily, but this stimulates migration to the main city. By assumption the median voter is in the hinterland; so, if the hinterland tax is too high, a democratic government may be voted out. A dictatorial government does not face this prospect; so its hinterland tax can be higher, causing an increase in main-city size in a dictatorship relative to a democracy.

A greater propensity to revolt - political instability - also increases main-city size in the AG model because the government placates rebellious residents by reducing the main-city tax, which stimulates migration to the main city. In the model, political instability has a smaller effect in a dictatorship than in a democracy. A larger differential exists between city and hinterland taxes in a dictatorship than in a democracy, making the main city larger in the dictatorship. Because the main city is smaller in a democracy, an increase in political instability results in a larger effect on main-city population than it does under a dictatorship. Therefore, the city-size effect is greater in a less stable democracy than in a less stable dictatorship.

AG test these propositions with a dictatorship variable, an instability variable, and the interaction of the two. Their model implies that main-city size will be greater under a dictatorship and will increase with political instability. It also predicts that political instability will make the main city larger under a democracy than it would under a dictatorship. Their dictatorship variable is a dummy variable taking the value of one if countries do not protect political rights, as measured by the Gastil index of political rights. We use a similar dictatorship variable (See Appendix A for variable definitions and sources). They measure political instability by the average number of revolutions and coups; our political instability variable is similar. Interacting political stability with the dictatorship variables allows a test of the hypothesis that political instability increases main-city size more in a democracy than in a dictatorship.

In our empirical analysis, we first replicate the AG basic equations with our 
data. We obtain results similar to theirs, suggesting that any differences we find are due to different specifications and estimators rather than different samples. Table 3 presents three AG specifications of the cross-section model for main-city size and estimates of the models using main-city size (gigantism) and urban primacy as dependent variables. The first specification takes the dependent variable as a function of a dichotomous variable indicating whether the main city is the capital city, the logarithm of national population, the logarithm of land area, the logarithm of GDP per capita, the logarithm of the share of the labor force outside agriculture, and the logarithm of the share of exports in GDP; the estimated coefficients indicate that the capital-city effect and national population both increase main-city size - gigantism. Furthermore, gigantism increases with the share of nonagricultural labor and, in contrast to Gustavsson, decreases with export's share of GDP.

The second specification adds an indicator variable for the existence of a dictatorship. This equation differs from AG's equation 3 (AG, 1995, p.209) by only one variable. We have replaced nonurbanized population and the urbanized population outside the main city with national population. Table 3 gives our results for main-city size in column four and the AG results for the same equation in column five. Even though the samples differ, the results are consistent, conveying similar information. First, main-city size is negatively correlated with export shares. Second, main-city size increases with capital-city status, population, and labor outside agriculture. For these four variables, our results are quite similar to the AG results. Our coefficients of land and dictatorship are both positive, like the AG coefficients, but they are not significant.

The third specification adds the political instability variable and its interaction with the dictatorship variable. Like AG, we find that main-city size increases with dictatorship indicator and political instability and that the coefficient of their interaction is negative, indicating that political instability has a greater effect in a democracy than in a dictatorship.

Do the results from the gigantism equation carry over to the primacy equation? To answer, we regress urban primacy, measured as the logarithm of the population of the main city divided by the population of the second city, on these same variables. Similarities exist among the coefficients between the two equations. In particular, the export and capital city variables yield the same qualitative results. The coefficients of total population have different signs. Main-city size increases less than in proportion to population; thus, population has a positive coefficient. But it is less than 1, implying that the main-city share 
Table 3. Comparison of primacy and main city: The ades glaeser approach

\begin{tabular}{|c|c|c|c|c|c|c|c|}
\hline \multirow{3}{*}{ VARIABLE } & \multicolumn{2}{|c|}{ VERSION 1} & \multicolumn{3}{|c|}{ VERSION 2} & \multicolumn{2}{|c|}{ VERSION 3} \\
\hline & PRIMACY & GIGANTISM & PRIMACY & GIC & SM & PRIMACY & GIGANTISM \\
\hline & 1 & 2 & 3 & 4 & 5 & 6 & 7 \\
\hline Capital City Indicator & $\begin{array}{c}1.58 * * * \\
(3.94)\end{array}$ & $\begin{array}{l}0.69 * * \\
(2.66)\end{array}$ & $\begin{array}{l}1.41 * * * \\
(3.40)\end{array}$ & $\begin{array}{l}0.57 * * \\
(2.14)\end{array}$ & $\begin{array}{l}0.37 * * \\
(2.07)\end{array}$ & $\begin{array}{c}1.43 * * * \\
(3.30)\end{array}$ & $\begin{array}{l}0.51 * * \\
(2.08)\end{array}$ \\
\hline Arable Land (ln) & $\begin{array}{l}0.30^{*} \\
(1.68)\end{array}$ & $\begin{array}{c}0.09 \\
(0.80)\end{array}$ & $\begin{array}{c}0.27 \\
(1.56)\end{array}$ & $\begin{array}{c}0.07 \\
(0.67)\end{array}$ & $\begin{array}{l}0.12 * * \\
(2.35)\end{array}$ & $\begin{array}{c}0.28 \\
(1.55)\end{array}$ & $\begin{array}{l}0.05 \\
(0.49)\end{array}$ \\
\hline GDP per Capita (ln) & $\begin{array}{c}0.32 \\
(0.93)\end{array}$ & $\begin{array}{c}0.12 \\
(0.55)\end{array}$ & $\begin{array}{c}0.42 \\
(1.24)\end{array}$ & $\begin{array}{c}0.20 \\
(0.90)\end{array}$ & $\begin{array}{c}0.17 \\
(1.30)\end{array}$ & $\begin{array}{c}0.47 \\
(1.27)\end{array}$ & $\begin{array}{c}0.32 \\
(1.54)\end{array}$ \\
\hline $\begin{array}{l}\text { Nonagricultural Emp } \\
(\ln )\end{array}$ & $\begin{array}{l}-0.96 \\
(-1.35)\end{array}$ & $\begin{array}{l}1.01 * * \\
(2.22)\end{array}$ & $\begin{array}{l}-1.01 \\
(-1.43)\end{array}$ & $\begin{array}{l}0.99 * * \\
(2.19)\end{array}$ & $\begin{array}{c}2.70 * * * \\
(4.92)\end{array}$ & $\begin{array}{l}-1.13 \\
(-1.53)\end{array}$ & $\begin{array}{l}0.79^{*} \\
(1.87)\end{array}$ \\
\hline Political Instability & & & & & & $\begin{array}{c}3.85 \\
(0.57)\end{array}$ & $\begin{array}{l}9.43 * * \\
(2.43)\end{array}$ \\
\hline Pol. Instab*Dictatorship & & & & & & $\begin{array}{l}-2.53 \\
(-0.68)\end{array}$ & $\begin{array}{l}-5.28 * * \\
(-2.47)\end{array}$ \\
\hline R-Square & 0.53 & 0.91 & 0.57 & 0.92 & & 0.59 & 0.94 \\
\hline
\end{tabular}

The number in parentheses is the t-statistic. The number above it is the coefficient.

$* * *, * *$, and * indicate significance at the 99 percent, 95 percent, and 90 percent levels, respectively. 
of population declines as population increases. The negative population coefficient in the primacy equation, however, implies that the second city increases in size relative to the main city as population grows. Estimating both equations yields more information; specifically, it suggests that the size of the two cities in the upper tail of the size distribution of cities increases and becomes more equal with greater national population.

Important differences between the primacy equation and the main-city equation, however, are for industrialization (nonagricultural labor's share) and the political variables. The industrialization variable is positive and significant in the main-city equations, but it is negative and larger than its standard error in the primacy equation. Similarly, the political variables are significant in the main-city equation, but they are not significant in the primacy equation. Note, however, that the dictatorship variable takes a similar value in both sets of equations, and is about one and one-half times its standard error in the primacy equation.

The comparison of the primacy and gigantism equations shows that studying gigantism is not equivalent to studying primacy; the AG political and industrialization results for main-city size do not carry over to primacy. Furthermore, Krugman's stylized facts are not well supported. In particular, the concentration of political power (except the capital city effect) and GDP per capita are not significant determinants of primacy, and GDP per capita is not associated with main-city size. ${ }^{6}$

Rejecting the stylized facts is premature, however, as is concluding that the results of the gigantism equation do not carry over to a primacy equation. First, interpretation of the results requires careful attention to the specification. For instance, the coefficient of the logarithm of GDP per capita is insignificant in Table 3 , but if we respecify the independent variables as the logarithms of population density, GDP, and GDP per capita, we obtain a significant positive coefficient for GDP per capita in the gigantism equation. ${ }^{7}$ Second, and more important, we examine the robustness of the results by exploiting the richness of the panel data computing fixed-effects estimates of the AG equation.

\footnotetext{
${ }^{6}$ In fact, AG found that omitting the nonagricultural employment share resulted in a positive, not negative, coefficient for GDP per capita.

${ }^{7}$ Because this is simply a rearrangement of the multiplicative population, land, and GDP terms, there is no effect on the estimates of the other coefficients (These results are not reported; they are available upon request).
} 


\section{The Determinants of Gigantism and Urban Primacy: A Panel Approach}

AG consider and reject using a panel estimator because it requires putting "some structure on how lagged values of country characteristics change current urban concentration" (p.204, fn. 9). Instead they use averages of the four observations for each cross-section unit; similarly, Gustavsson uses averages over a decade. In effect, they use the between estimator rather than the dummy-variable or within estimator. By using the between estimator, they neglect the information contained in the temporal variation of the cross-section units (Judge et al., 1988). If urbanization patterns respond to growth in population density or to technical change that increases GDP or GDP per capita, ignoring the temporal variation within the cross-section unit sacrifices substantial information ${ }^{8}$.

The between estimator uses a single cross section and thus eliminates the possibility of using country effects to capture omitted variables. Gustavsson's parsimonious equation uses rural population density and road density to control what she calls the push-pull effects and internal trade costs. In a second equation she adds GDP per capita. AG, in contrast, use several control variables. Both Gustavsson and AG are aware of the bias introduced by omitted variables and thus attempt to include appropriate control variables. Nevertheless, cross-sectional analysis of country data risks the omission of important fixed factors that affect urban concentration. Examples might be a country's colonial history or its geography. Henderson (1996), in his discussion of Krugman's urban concentration models, emphasizes that some of Krugman's results depend upon initial conditions. Specifically, he states, "the impact of trade on national space is situation specific, depending upon the precise geography of the country" (p.33). We believe that Henderson's comments about the situation-specific nature of the impact of trade also apply to political, transportation, and other impacts, calling for recognition of the potential importance of country effects in estimating gigantism and primacy equations. Consequently, we are willing to assume that the independent variables have a contemporaneous effect on primacy, because by doing so we capture the

\footnotetext{
${ }^{8}$ It has been suggested that with panel data in 5-year intervals, we are assuming rapid adjustment. If some variable, say exports or dictatorship, affect primacy with a significant lag, then the short intervals may give misleading results. To check the effect of intervals, we estimated the second set of primacy and main-city equations in Tables 3 and 4, using 10 year intervals, reducing our cross-sections to four. The results of this estimate (available upon request) are very similar to those using 5-year intervals. Consequently, we continue the analysis with the 5 -year intervals because they use more information.
} 
temporal variation in the cross-section unit and, importantly, we can include country fixed effects, which reduces the risk of omitted variable bias.

The results presented in Table 4 correspond to specifications 1 and 2 in Table 3. Because we treat political factors as time invariant (except for capital city and dictatorship), we do not have an estimate that corresponds to specification 3 in Table 3. We tested for random effects and found in most cases that they were correlated with the regressors. Consequently, we use the dummy-variable estimator.

An examination of the first four columns in Table 4 shows substantive changes from Table 3: First, GDP per capita is positively associated with main-city size and primacy. It does not, therefore, support Krugman's stylized fact regarding the relationship between income per capita and urban concentration. Second the coefficient of nonagricultural labor is positive and significant for both main-city size and primacy. Thus, in the fixed effects estimates, the coefficients of two development indicators, GDP per capita and nonagricultural labor, suggest that urban concentration, however measured, increases with development. Although it was not so in Table 3, the coefficient of the dictatorship variable is significant in the primacy equation, but unlike the AG result it is not significant in the main-city equation. The final important change is that export's share of GDP loses significance in both equations. In contrast, the capital-city variable and the population variable have the same qualitative effects as in Table 3. Finally the land variable does not have significant coefficients.

So far, two of Krugman's stylized facts concerning urban concentration are not supported in the panel-data analysis. Concentration does not decrease with development and open economies do not show less concentration. To delve deeper into the development and concentration issue, we rewrite the specification to emphasize population density, GDP, and GDP per capita. It currently is $\ln y=\ln \alpha$ $+\beta \ln \mathrm{POP}+\chi \ln \mathrm{LAND}+\delta \ln (\mathrm{GDP} / \mathrm{POP})+($ other variables, parameters, and error terms) where POP is population and LAND is land area. With algebraic manipulation, it can be written as $\ln \mathrm{y}=\ln \alpha-\chi \ln (\mathrm{POP} / \mathrm{LAND})+(\delta-\beta-\chi) \ln$ $(\mathrm{GDP} / \mathrm{POP})+(\beta+\chi) \ln \mathrm{GDP}+$ (other terms). By showing primacy and main-city size as functions of population density, GDP per capita, and GDP, this version of the equation relates better to the tension between transportation costs and economies of scale. AG argue that population density proxies for transportation cost, with the expectation that greater density implies lower transportation cost and less urban concentration. Henderson (1988) and Wheaton and Shishido (1981) expect urban concentration to increase with GDP per capita, perhaps reaching a 
Table 4. Comparison of primacy and main city fixed effects models

\begin{tabular}{|c|c|c|c|c|c|c|c|c|}
\hline VARIABLE & PRIMACY & GIGANTISM & PRIMACY & GIGANTISM & PRIMACY & GIGANTISM & PRIMACY & GIGANTISM \\
\hline & 1 & 2 & 3 & 4 & 5 & 6 & 7 & 8 \\
\hline $\begin{array}{l}\text { Capital City } \\
\text { Indicator }\end{array}$ & $\begin{array}{c}0.57 * * * \\
(3.43)\end{array}$ & $\begin{array}{c}0.61 \\
(5.62)\end{array}$ & $\begin{array}{c}0.55^{* * * *} \\
(3.36)\end{array}$ & $\begin{array}{c}0.61 * * * \\
(5.61)\end{array}$ & $\begin{array}{c}0.57 * * * \\
(3.43)\end{array}$ & $\begin{array}{c}0.61 \\
(5.62)\end{array}$ & $\begin{array}{c}0.55^{* * * *} \\
(3.37)\end{array}$ & $\begin{array}{c}0.61 * * * \\
(5.61)\end{array}$ \\
\hline Population (ln) & $\begin{array}{c}-0.51 * * * \\
(-4.06)\end{array}$ & $\begin{array}{c}0.85^{* * * *} \\
(10.32)\end{array}$ & $\begin{array}{c}-0.58 * * * \\
(-4.48)\end{array}$ & $\begin{array}{c}0.86^{* * * *} \\
(10.13)\end{array}$ & & & & \\
\hline Arable Land (ln) & $\begin{array}{c}0.06 \\
(0.60)\end{array}$ & $\begin{array}{c}0.10 \\
(1.36)\end{array}$ & $\begin{array}{c}0.11 \\
(1.01)\end{array}$ & $\begin{array}{c}0.09 \\
(1.26)\end{array}$ & & & & \\
\hline $\begin{array}{l}\text { Nonagricultural } \\
\text { Emp (ln) }\end{array}$ & $\begin{array}{c}0.57 * * * \\
(2.64)\end{array}$ & $\begin{array}{c}0.67 * * * \\
(4.73)\end{array}$ & $\begin{array}{c}0.65^{* * *} \\
(3.01)\end{array}$ & $\begin{array}{c}0.66^{* * * *} \\
(4.57)\end{array}$ & $\begin{array}{c}0.57 * * * \\
(2.64)\end{array}$ & $\begin{array}{c}0.67 * * * \\
(4.73)\end{array}$ & $\begin{array}{c}0.65^{* * * *} \\
(3.01)\end{array}$ & $\begin{array}{c}0.66^{* * * *} \\
(4.57)\end{array}$ \\
\hline $\begin{array}{l}\text { Export/GDP } \\
\text { (ln) }\end{array}$ & $\begin{array}{l}-0.04 \\
(-0.85)\end{array}$ & $\begin{array}{c}0.02 \\
(0.46)\end{array}$ & $\begin{array}{l}-0.04 \\
(-0.84)\end{array}$ & $\begin{array}{c}0.02 \\
(0.46)\end{array}$ & $\begin{array}{c}-0.04 \\
(-0.85)\end{array}$ & $\begin{array}{c}0.02 \\
(0.46)\end{array}$ & $\begin{array}{l}-0.04 \\
(-0.84\end{array}$ & $\begin{array}{c}0.02 \\
(0.46)\end{array}$ \\
\hline GDP (ln) & & & & & $\begin{array}{c}-0.45^{* * *} \\
(-3.41)\end{array}$ & $\begin{array}{c}0.95^{* * * *} \\
(11.04)\end{array}$ & $\begin{array}{c}-0.47 * * * \\
(-3.57)\end{array}$ & $\begin{array}{c}0.95^{* * * *} \\
(11.01)\end{array}$ \\
\hline R-Square & 0.96 & 0.99 & 0.96 & 0.99 & 0.96 & 0.99 & 0.96 & 0.99 \\
\hline
\end{tabular}

The number in parentheses is the t-statistic. The number above it is the coefficient.

$* * *, * *$, and $*$ indicate significance at the 99,95 , and 90 percent levels, respectively. 
maximum and decreasing. Finally, Moomaw and Shatter (1996) argue that as the size of the economy increases, the concomitant division and specialization of labor (Smith, 1776; Stigler, 1951; and Evans, 1972) allows industries and countries to disperse, achieving economies of specialization at a smaller size. Because efficient production facilities can be located at more sites, transportation cost can be reduced by dispersal without sacrificing production efficiency. The coefficient of size, of GDP, is expected to be negative.

Columns 5-8 in Table 4 show the estimates of the rewritten equation; the coefficients of the capital city indicator, nonagricultural employment, exports as a share of GDP, and the dictatorship indicator are necessarily the same as in the first four columns because the basic equation has not changed ${ }^{9}$. The most important results come from the coefficients of GDP and GDP per capita. The coefficient of GDP, of course, shows the effect of a change in GDP, holding other variables in the equation constant. To increase GDP and hold constant population density, GDP per capita, and exports as a proportion of GDP, it is necessary to increase population, exports, and land area by the same proportion. Therefore, the coefficient of GDP gives the effect of a proportionate increase in four dimensions of an economy's size- population, area, GDP, and exports; it is positive for main-city size (gigantism) and negative for primacy. Larger economies, in this sense, have larger main cities, but the increase in main-city size is not larger than the increase in economic size, i.e., not greater than 1 . Furthermore, the negative coefficient in primacy equation implies that the proportionate increase in the size of the second city is larger than that of the main city.

GDP per capita's coefficient, just as the sign of GDP's coefficient, differs in the two equations, but it is negative for main-city size and positive for primacy. A ceteris paribus change in GDP per capita is obtained by reducing population and land area by the same proportion, holding GDP constant. Economy A has the same GDP as economy $\mathrm{B}$, but economy $\mathrm{B}$ has a smaller population and a smaller land area. Economy B, therefore, has a greater GDP capita and a greater GDP per unit of land. Because economy $\mathrm{B}$ has a smaller population it is not surprising that it has a smaller main-city size. What may be surprising is that its primacy is greater, implying that second-city size decreases more than main city size. In short, primacy increases with GDP per capita. This increase in primacy may be

\footnotetext{
${ }^{9}$ Although these coefficients can be calculated from the estimates in the first four columns, reestimating the equations is a convenient way to get the standard errors and t-statistics for the new coefficients.
} 
interpreted as the concentrating effect of a more advanced technology (Henderson, 1988) or a demand effect related to the income elasticity of demand for main-city goods. The results for GDP and GDP per capita suggest that the appropriate stylized fact is that "large" economies have less primacy or less urban concentration than "small" economies rather than the rich-poor comparison that Krugman makes. We find that economies with greater levels of development, as measured by GDP per capita and industrialization (nonagricultural employment as a share of total employment) have greater primacy than economies that are less developed $^{10}$.

Although we confirm the basic AG findings regarding main-city size, their results cannot simply be applied to primacy or presumably to other measures of urban concentration. In analyzing urban concentration - main-city size, primacy, or other measures - we believe that panel-data results provide information beyond that obtained from between estimators or other cross-section estimators. To this point, however, the panel approach does not support AG's results regarding international-trade costs and political variables. In the next section, we examine these issues.

\section{The Effects of International Trade and Internal Politics on Gigantism and Primacy}

In the fixed-effects estimates the export share of GDP does not have a significant coefficient in any of the equations. Furthermore, because we did not have appropriate data, we were unable to test the political instability hypotheses with panel data. In this section we explain why we think the export variable was insignificant and provide evidence that trade and trade openness are associated with lower levels of urban concentration, supporting the Krugman hypothesis. We also support AG's hypotheses regarding political instability, dictatorship, and gigantism, but these results do not carry over to primacy.

The fixed-effects equations rely on temporal variation in each country to estimate the relevant coefficients. Just as the between estimator downplays temporal

\footnotetext{
${ }^{10}$ Population density has a negative correlation with both measures of urban concentration. Its marginal probabilities ( $p$ values) for the gigantism equations are 0.21 and 0.17 . Because land area is measured as arable land, it has temporal variation for a number of countries. It does not vary as much over time, however, as variables such as GDP per capita and population. Although it varies enough to estimate the dummy-variable equation, its lesser temporal variation may account for its insignificant coefficients. Consequently, we do not emphasize the land and population density results.
} 
variation, the fixed-effect estimator downplays cross-sectional variation. For variables with limited temporal variation, it is not surprising to find their coefficients insignificant in fixed-effects estimates. We believe that political instability is a variable that has limited temporal variation for many countries. Has a country that has several revolutions and coups over a five-year span followed by a five-year span of no such events developed greater stability? Perhaps, but it may also be that the propensity has not changed. If its political institutions become freer from one period to the next, does the ability of its government to exploit the hinterland without being booted out change? Again, perhaps.

The importance of imports and exports in affecting a country's economic geography also has an element of inertia. It depends on the economic and political benefits and costs of free trade. If these benefits and costs change slowly, then an increased proportion of exports in GDP from one period to the next may indicate a more open trade policy or it may be short-term effect subject to reversal. Consequently, it might not be wise to make site-specific investments in response to the availability of foreign inputs and markets. Perhaps the trade regime will be reversed. If the trade and political variables have little variation in the time series and more variation in the cross section, it may be more appropriate to consider them as fixed for the panel. We can test the importance of such variables by recovering and attempting to explain the fixed effects. To do so, we use averaged export shares and averaged political variables as regressors. The first step is to retrieve the fixed effects from equations like those in Table 4 . Because we are assuming trade and political factors fixed, we recover the fixed effects from new estimates that omit the export-share and the dictatorship variables. Because we are particularly interested in the international trade variable we present four sets of regressions with each set using a different trade variable. The first trade variable is the export-share variable: because it is a measure, however crude, of the international purchases and sales of goods and services. It is these actual foreign purchases and sales that allow firms to loosen their ties with an economy's main city. The other trade measures are TARIFF, NONTARIFF, and POTENTIAL (Lee, 1993). TARIFF is a weighted average of 1988 tariffs on a country's imports of intermediate inputs and capital goods, and NONTARIFF is a measure of other barriers to the same imports. POTENTIAL is computed based on a country's area and its distance from important trading partners. Because POTENTIAL is computed using a country's geography - its area and its location relative to other countries - it is a particularly appropriate given our interest in new economic 
geography.

The first four columns of Table 5 report regressions using the average export share of GDP as the measure of international-trade costs. Countries with larger average export shares have smaller main cities $(p=0.15)$ and lower primacy $(p=$ $.01)$. This is consistent with one of Krugman's stylized facts and suggests that, other things equal, a more open economy has a greater extent of the market, allowing greater spatial dispersal of economic activity. The equations with other trade variables are in columns 5-10. The coefficients of the trade variable in the three additional gigantism equations are not close to significance, but they are significant in two of the three additional primacy equations, with signs that support the Krugman hypothesis. The positive sign on the trade variable, when it is measured by tariffs, of course, says that trade restrictions are associated with increased primacy, or that reducing restrictions is associated with reduced primacy. When the trade variable is measured by potential, the negative sign for the primacy equation is consistent with the Krugman hypothesis ${ }^{11}$. No support is found for the Gustavsson result that reductions in international-trade costs increase primacy or gigantism.

Dictatorship, political instability, and their interaction are significant in the gigantism equation, using the average export share (columns 1 and 2), just as they are in Table 3 and in AG. Dictatorship is significant in the gigantism equations with the three other trade variables and political instability and the interaction variable have the expected signs. Political instability and the interaction variable were not significant in the first primacy equation, so they not included in the last 3 estimates. The dictatorship variable is consistently positive in the primacy equations, and it was significant for primacy in the fixed-effects estimates in Table 3.

The finding that political instability does not increase primacy but does increase the size of the main city is revealing. It suggests that in unstable, democratic societies the hinterland is a dangerous place, stimulating movement to the larger cities, where government can more easily provide protection. It is not, however, just to the main city to which people flee from the hinterland; they also flee to the second and perhaps other large cities. Thus, the main-city effect tends to positive, but the primacy effect is not significant.

Now introduce dictatorship into a society of average instability. Other things

\footnotetext{
${ }^{11}$ Based on the results for column 2, the specification for the remaining primacy equations omits the interaction of dictatorship and instability.
} 
Table 5. Political Determinants of Fixed Effects

\begin{tabular}{|c|c|c|c|c|c|c|c|c|c|c|}
\hline \multirow[b]{2}{*}{ VARIABLE } & \multicolumn{4}{|c|}{ AVERAGE EXPORT SHARE } & \multicolumn{2}{|c|}{ TARIFF } & \multicolumn{2}{|c|}{ NON TARIFF } & \multicolumn{2}{|c|}{ POTENTIAL } \\
\hline & $\begin{array}{l}\text { GIGAN- } \\
\text { TISM }\end{array}$ & PRIMACY & $\begin{array}{l}\text { GIGAN- } \\
\text { TISM }\end{array}$ & PRIMACY & $\begin{array}{c}\text { GIGAN- } \\
\text { TISM }\end{array}$ & PRIMACY & $\begin{array}{l}\text { GIGAN- } \\
\text { TISM }\end{array}$ & PRIMACY & $\begin{array}{c}\text { GIGAN- } \\
\text { TISM }\end{array}$ & PRIMACY \\
\hline & 1 & 2 & 3 & 4 & 5 & 6 & 7 & 8 & 9 & 10 \\
\hline Constant & $\begin{array}{c}-3.77 \\
(-8.94)\end{array}$ & $\begin{array}{c}4.49 \\
(5.26)\end{array}$ & $\begin{array}{c}-3.37 \\
(-9.17)\end{array}$ & $\begin{array}{c}4.72 \\
(6.71)\end{array}$ & $\begin{array}{l}-3.80 \\
(8.76)\end{array}$ & $\begin{array}{c}3.51 \\
(4.72)\end{array}$ & $\begin{array}{c}-3.68 \\
(-7.53)\end{array}$ & $\begin{array}{c}3.87 \\
(4.64)\end{array}$ & $\begin{array}{l}-3.75 \\
(-6.84)\end{array}$ & $\begin{array}{c}5.31 \\
(6.11)\end{array}$ \\
\hline Trade Variable & $\begin{array}{l}-0.01 \\
(1.49)\end{array}$ & $\begin{array}{l}-0.05^{* * * *} \\
(2.89)\end{array}$ & $\begin{array}{l}-0.01 \\
(1.16)\end{array}$ & $\begin{array}{c}-0.05^{* * *} \\
(2.89)\end{array}$ & $\begin{array}{c}-0.32 \\
(-0.94)\end{array}$ & $\begin{array}{l}1.63 * * \\
(2.35)\end{array}$ & $\begin{array}{l}-0.30 \\
(-0.84)\end{array}$ & $\begin{array}{c}0.51 \\
(0.69)\end{array}$ & $\begin{array}{l}-0.63 \\
(-0.35)\end{array}$ & $\begin{array}{l}-8.41 * * \\
(-2.43)\end{array}$ \\
\hline $\begin{array}{l}\text { Average Dictatorship } \\
\text { Indicator }\end{array}$ & $\begin{array}{l}0.58 * * \\
(2.12)\end{array}$ & $\begin{array}{c}0.85 \\
(1.64)\end{array}$ & $\begin{array}{c}0.31 \\
(1.44)\end{array}$ & $\begin{array}{l}0.70^{*} \\
(1.68)\end{array}$ & $\begin{array}{l}0.48^{*} \\
(1.87)\end{array}$ & $\begin{array}{c}0.62 \\
(1.43)\end{array}$ & $\begin{array}{c}0.40 \\
(1.43)\end{array}$ & $\begin{array}{c}0.57 \\
(1.17)\end{array}$ & $\begin{array}{l}0.48^{*} \\
(1.82)\end{array}$ & $\begin{array}{c}0.66 \\
(1.51)\end{array}$ \\
\hline $\begin{array}{l}\text { Average Political } \\
\text { Instability }\end{array}$ & $\begin{array}{l}7.76^{*} \\
(1.79)\end{array}$ & $\begin{array}{c}3.63 \\
(0.41)\end{array}$ & $\begin{array}{c}0.40 \\
(0.64)\end{array}$ & $\begin{array}{l}-0.65 \\
(0.53)\end{array}$ & $\begin{array}{c}7.53 \\
(1.67)\end{array}$ & $\begin{array}{l}-0.49 \\
(-0.39)\end{array}$ & $\begin{array}{c}5.63 \\
(1.21)\end{array}$ & $\begin{array}{l}-0.69 \\
(-0.49)\end{array}$ & $\begin{array}{c}6.35 \\
(1.37)\end{array}$ & $\begin{array}{l}-0.58 \\
(-0.05)\end{array}$ \\
\hline $\begin{array}{l}\text { Dictatorship* } \\
\text { Political Instability }\end{array}$ & $\begin{array}{l}-4.09^{*} \\
(1.71) \\
\end{array}$ & $\begin{array}{l}-2.44 \\
(0.50) \\
\end{array}$ & & & $\begin{array}{c}-3.92 \\
(-1.59) \\
\end{array}$ & & $\begin{array}{l}-2.79 \\
(1.09) \\
\end{array}$ & & $\begin{array}{l}-3.25 \\
(1.27) \\
\end{array}$ & \\
\hline $\mathrm{R}^{2}$ & 0.12 & 0.18 & 0.05 & 0.24 & 0.07 & 0.13 & 0.06 & -0.06 & 0.04 & 0.14 \\
\hline
\end{tabular}

The number in parentheses is the t-statistic. The number above it is the coefficient.

***, **, and * indicate significance at the 99 percent, 95 percent, and 90 percent levels., respectively. 
equal, main-city size and primacy increase, implying that the size of the main city increases more than that of the second city. Consequently, dictatorship tends to concentrate population in the main city, whereas instability tends to concentrate it proportionately in the largest cities. Although the $t$ statistics are low for the political variables in the remaining gigantism equations, the signs of the coefficients are the same as in column 1 .

Our empirical results show that equations explaining main-city size cannot be applied ipso facto to primacy. The dictatorship variable and the capital city variable both provide support for Krugman's assertion that urban concentration is enhanced by political factors.

\section{Conclusion}

This paper has four purposes. The first is to provide additional information about the effect of international-trade costs on urban concentration. The second is to examine the associations between economic development and urban concentration. The third is to determine if the AG results regarding main-city size apply to urban primacy and thus determine if gigantism and primacy are determined in the same way. The fourth is to provide information about Krugman's stylized facts. We have tentative conclusions for each purpose. Because we use the dummy-variable estimator, however, we cannot extend our inferences beyond the sample. Consequently, our conclusions are applicable only to countries in Asia and the Americas. Second, the economic and demographic economic data, particularly the city-size data and the political data, are not perfectly measured. With these provisos, we offer the following conclusions.

First, we find no support Gustavsson's result that openness or a greater importance of trade increases concentration. For these countries greater trade and trade potential has a strong negative effect on urban primacy. Openness to trade, however, has no effect on gigantism. This implies that as trade becomes more important, the second city, and perhaps other cities become larger.

Development has a positive association with both gigantism and primacy. Political factors also affect concentration, as evidenced by the capital-city effect, the dictatorship effect on primacy, and the combined political instability and dictatorship effects on gigantism.

Third, studying main-city size is neither empirically nor theoretically isomorphic to studying primacy 
Finally, the paper supports two of Krugman's propositions and an appropriately modified version of another one. In particular, urban primacy is less in more open economies, and it increases with concentration of political power. Contrary to Krugman, however, gigantism and primacy do not fall with GDP per capita; in our specification they increase. This is not a new result. Wheaton and Shishido find urban concentration increasing with GDP per capita up to a point, and Henderson's results implicitly suggest the same thing. Krugman's theoretical arguments appear to be related more to the size of the market than to economic development. Our results show a strong negative relationship between primacy and the size of the market. Similarly, the size of the largest city does not increase as fast as the size of the economy, suggesting that the largest becomes relatively less important as the economy gets larger.

Received October 13, 2004, Accepted September 2005

\section{References}

Ades, A.F. and E.L. Glaeser (1995), "Trade and Circuses: Explaining Urban Giants," Quarterly Journal of Economics, 110, 195-227.

Barro, R.J. (1991), "Economic Growth in a Cross-Section of Countries," The Quarterly Journal of Economics, CVI (2), 407-443.

Brakman, S., H. Garretsen, and C. van Marrewijk (2001), An Introduction to Geographical Economics, Cambridge University Press.

Brueckner, J.K. (1990), “Analyzing Third World Urbanization: A Model with Empirical Evidence," Economic Development and Cultural Change, 38(3), 587-610.

Evans, A.W. (1972) "The Pure Theory of City Size in an Industrial Economy," Urban Studies, 9, 49-78.

Gastil, R., Freedom in the World, Westport: Greenwood Press (different years).

Gustavsson, R. (1999), "Explaining the Phenomenon of Third World Urban Giants," Journal of Economic Integration, 14(4), 625-650.

Fujita, M., P.R. Krugman and A.J. Venables (1999), The Spatial Economy: Cities, Regions, and International Trade: Cambridge: MIT Press.

Henderson, J. V. (2000), "How Urban Concentration Affects Economic Growth, World Bank Group, Policy Research Working Papers, \#2326.

Henderson, J.V. (1996), "Ways to Think about Urban Concentration: Neoclassical Urban Systems versus the New Economic Geography." International Regional Science Review, 19, 31-36.

Henderson, J.V. (1988), Urban Development: Theory, Fact, and Illusion, Oxford: Oxford University Press. 
Judge, Hill, Griffiths, Lutkepohl, and Lee (1988), Introduction to the Theory and Practice of Econometrics: Second Edition, New York: John Wiley and Sons.

Jefferson, M. (1939, April), “The Law of the Primate City," Geographical Review, 29, 226-232.

Krugman, P. (1996), "Urban Concentration: The Role of Increasing Returns and Transportation Costs," International Regional Science Review, 19, 5-30.

Krugman, P. and R. Livas Elizondo (1996), "Trade Policy and the Third World Metropolis," Journal of Development Economics, 49, 137-50.

Lee, Jong-Wha, "International Trade, Distortions and Long-run Economic Growth," IMF Staff Papers, June 1993.

Moomaw, R.L. and A.M. Shatter (1996), "Urbanization and Economic Development: A Bias Toward Large Cities?," Journal of Urban Economics, 40. 13-37.

Mutlu, S. (1989), "Urban Concentration and Policy Revisited: An Analysis and Some Policy Conclusions," Economic Development and Cultural Change, 37(3), 611-39.

Rosen, K.T. and M. Resnick (1980), "The Size Distribution of Cities: An Examination of the Pareto Law and Primacy," Journal of Urban Economics, 8, 165-186.

Sawers, L. (1989). "Urban Primacy in Tanzania," Economic Development and Cultural Change, 37(4), 841-59.

Stigler, G. J. (1951), "The Division of Labor is Limited by the Extent of the Market, Journal of Political Economy (1951); in The Organization of Industry (G.J. Stigler, Ed.), Irwin, Homewood, IL (1968).

United Nations (1987), The Prospects of World Urbanization, New York: UN, Department of International Economic and Social Affairs.

United Nations (1993), World Urbanization Prospects: The 1992 Revision, New York: UN Department of Economic and Social Information and Policy Analysis.

United Nations (different issues), Demographic Yearbook, New York: Department of International Economic and Social Affairs

Wheaton, W.C. and H. Shishido (1981), "Urban Concentration, Agglomeration Economies, and the Level of Economic Development," Economic Development and Cultural Change, 30, 17-30.

World Bank (Different Issues), World Development Report, New York: Oxford University Press.

\section{Appendix A: Variables and Sources}

PRIMACY - is the ratio of the largest city population to the population of the second largest city.

GDP - gross domestic product. GDP is calculated from the Penn World Tables (Mark 5.6).

GDPC - gross domestic product per capita. Source: The Penn World Tables (Mark 
5.6).

$\mathrm{POP} /$ Land - population density, which is the ratio of the total population to the arable land. Sources: total population data are from The UN World Urbanization Prospects: The 1992 Revision; arable land data are from FAO Production Yearbook.

DCAP - dummy variable that equals 1 if the capital city is also the largest city and equals 0 otherwise. Sources: UN Demographic Yearbook, and World Urbanization Prospects: The 1992 Revision.

EXPORT/GDP - exports of goods and nonfactor services as a percentage of GDP. Sources: World Tables, 1994 and different issues of World Development Report.

Nonagricultural employment - share of labor outside agriculture. It is calculated as 1 minus the percentage of economically active population in agriculture. Source: FAO Production Yearbook.

EXPORT - the ratio of export of goods and nonfactor services to GDP averaged over the year 1960 to 1990 .

DICT - dictatorship variable $(1=$ free, 2 = partially free, $3=$ not free). Sources: different issues of Gastil's Freedom in the World, and Bollen (1990), for crosssectional data, it is averaged over 1975, 1980, 1985, and 1990.

POLINS - measures of political instability. ( $0.5 *$ assassination $+0.5 *$ revolution $)$, average of 1965, 1970, 1975, 1980, and 1985. Source: Barro and Wolf (1990).

Population of the largest city population. Sources: UN Demographic Yearbook and World Urbanization Prospects. The 1992 Revision

* Data for the Republic of China (Taiwan) are from different issues of The Republic of China Statistical Yearbook, The Europa Yearbook, and The Statesman's Yearbook. 